\title{
Effects of rhizobacteria Paenibacillus polymyxa APEC136 and Bacillus subtilis APEC170 on biocontrol of postharvest pathogens of apple fruits*
}

\author{
Young Soo KIM ${ }^{1}$, Kotnala BALARAJU², Yongho JEON $\$ \$ 1,2$ \\ ( ${ }^{1}$ Department of Bioresource Sciences, Andong National University, Andong 36729, Korea) \\ ( ${ }^{2}$ Agricultural Science and Technology Research Institute, Andong 36729, Korea) \\ †E-mail: yongbac@andong.ac.kr \\ Received Mar. 14, 2016; Revision accepted July 12, 2016; Crosschecked Nov. 17, 2016
}

\begin{abstract}
In this study, plant growth-promoting rhizobacteria (PGPR) were evaluated as potential biocontrol agents against postharvest pathogens of apple fruits. In vitro bioassays revealed that, out of 30 isolates screened, isolates APEC136 and APEC170 had the most significant inhibitory effects against the mycelial growth of several fungal pathogens. Analysis of $16 \mathrm{~S}$ ribosomal RNA (rRNA) sequences identified the two effective isolates as Paenibacillus polymyxa and Bacillus subtilis, respectively. The two strains showed greater growth in brain-heart infusion broth than in other growth media. Treatment of harvested apples with suspensions of either strain reduced the symptoms of anthracnose disease caused by two fungal pathogens, Colletotrichum gloeosporioides and Colletotrichum acutatum, and white rot disease caused by Botryosphaeria dothidea. Increased productions of amylase and protease by APEC136, and increased productions of chitinase, amylase, and protease by APEC170 might have been responsible for inhibiting mycelial growth. The isolates caused a greater reduction in the growth of white rot than of anthracnose. These results indicate that the isolates APEC136 and APEC170 are promising agents for the biocontrol of anthracnose and white rot diseases in apples after harvest, and suggest that these isolates may be useful in controlling these diseases under field conditions.
\end{abstract}

Key words: Anthracnose, Antagonistic activity, Biological control, White rot, Apple

http://dx.doi.org/10.1631/jzus.B1600117

CLC number: S476

\section{Introduction}

Postharvest diseases of fruits cause considerable losses of up to $20 \%-25 \%$ during transportation in most developed countries (Droby, 2006; Zhu, 2006). Despite the use of synthetic fungicides for their control, postharvest diseases still cause economic losses during postharvest handling worldwide (Kelman, 1989). Most fruit species grown in temperate regions are highly susceptible to anthracnose disease, which

\footnotetext{
¿ Corresponding author

* Project supported by the 2016 Research Fund of Andong National University, Gyeongbuk Province, Korea

(D) ORCID: Young Soo KIM, http://orcid.org/0000-0001-5658-6889; Yongho JEON, http://orcid.org/0000-0001-8182-2548

(C) Zhejiang University and Springer-Verlag Berlin Heidelberg 2016
}

is caused by Colletotrichum gloeosporioides and Colletotrichum acutatum (Wharton and DiéguezUribeondo, 2004). Both these fungal pathogens have been found in various fruits, including apples, in Korea (Lee et al., 2007). Anthracnose is a potentially destructive disease that affects apples, particularly under hot and humid conditions (Mari et al., 2012). White rot disease, caused by Botryosphaeria dothidea, is one of the most important diseases of apple fruits in Korea (Kim et al., 2005). The pathogen also occurs in Japan (Ogata et al., 2000) and China (Tang et al., 2012), and causes dieback disease in blueberries (Choi, 2011). The control of white rot disease is dependent mainly on the use of chemical fungicides (Chen et al., 2016). Apple cultivars are susceptible to various pathogens including Penicillium expansum or 
Botrytis cinerea that can cause losses during the postharvest period. Biocontrol of postharvest diseases depends on the specific pathogen and biocontrol agent (Teixidó et al., 2011; Talibi et al., 2014). Typically, chemical treatments, including methyl bromide are used to control postharvest diseases of apples. However, many biocontrol agents have been introduced as alternatives in recent years (Droby et al., 2009; Mari et al., 2009; Teixidó et al., 2011).

The soil bacterium Paenibacillus polymyxa belongs to a group of plant growth-promoting rhizobacteria (PGPR) and is used as a biocontrol agent for plant diseases (Dijksterhuis et al., 1999; Li et al., 2015). Previous studies have demonstrated that $P$. polymyxa treatment is associated with various plant activities, including nitrogen fixation (Heulin et al., 1994), solubilization of soil phosphorus (Singh and Singh, 1993), and production of various antibiotics (Rosado and Seldin, 1993). Bacillus spp. can produce a wide spectrum of secondary metabolites that are diverse in both structure and function (Touré et al., 2004). They occur in extreme environments and are one of the main sources of potential microbial pesticides since they retain several valuable traits (Ongena and Jacques, 2008). Bacillus subtilis is a well-studied microorganism that is recognized as non-pathogenic and is able to produce spores and tolerate high temperatures (Piggot and Hilbert, 2004). Haas and Défago (2005) reviewed the availability of commercial biocontrol agents and their specific derived products against target pathogens on target crop plants. Similarly, Yánez-Mendizábal et al. (2012) developed effective formulations of the biocontrol agent $B$. subtilis CPA-8 and used a spray-drying method to control peach and nectarine brown rot caused by Monilinia spp.

Using microorganisms for the biological control of fruit diseases has long been an effective alternative to chemical control. Microorganisms possessing antimicrobial activity have been extensively studied as biocontrol agents against various soil-borne pathogens (Liu et al., 2013). However, the effectiveness of $P$. polymyxa and $B$. subtilis strains in controlling postharvest diseases in apples is largely unknown. Therefore, the purpose of this study was to investigate the biocontrol potential of the $P$. polymyxa APEC136 and B. subtilis APEC170 isolates of those species for controlling anthracnose and white rot disease in harvested apples.

\section{Materials and methods}

\subsection{Isolation of rhizosphere bacteria}

Soil samples (50 g) were collected from several apple orchards in Andong, Gyeongbuk Province, Korea, from which bacteria were isolated using the dilution plating method (Dhingra and Sinclair, 1985; Kim et al., 2016). Collected samples were stored at $4{ }^{\circ} \mathrm{C}$ in sterile plastic bags until used. Subsamples $(5 \mathrm{~g})$ were diluted with $45 \mathrm{ml}$ of sterile distilled water (SDW), thoroughly dispersed by shaking (150 r/min) for $30 \mathrm{~min}$ at $28^{\circ} \mathrm{C}$, and further diluted $10^{3}-10^{7}$ fold. Aliquots $(100 \mu \mathrm{l})$ of the diluted samples were spread onto nutrient agar (NA) plates and incubated at $28^{\circ} \mathrm{C}$ for $24 \mathrm{~h}$. Individual colonies were then picked and streaked on freshly prepared NA plates. The isolated strains were maintained at $-50{ }^{\circ} \mathrm{C}$ in nutrient broth (NB) with glycerol $(20 \%, \mathrm{v} / \mathrm{v})$ for long-term storage. To prepare bacterial suspensions, cultures stored at $-50{ }^{\circ} \mathrm{C}$ were grown on NA medium for $48 \mathrm{~h}$ at $28^{\circ} \mathrm{C}$, and single colonies were transferred to $\mathrm{NB}$ and incubated for $24 \mathrm{~h}$ at $28^{\circ} \mathrm{C}$ with shaking at $150 \mathrm{r} / \mathrm{min}$. Bacteria were pelleted by centrifugation of the cultures for $5 \mathrm{~min}$ at $8000 \mathrm{~g}$ and were resuspended in SDW to a final concentration of $1 \times 10^{8}$ colony forming units per milliliter (CFU/ml; optical density at $600 \mathrm{~nm}$ $\left.\left(\mathrm{OD}_{600}\right)\right)$ before application.

\subsection{In vitro antagonism test}

The in vitro antagonism effects of all the bacterial isolates on the mycelial growth of $C$. gloeosporioides, $C$. acutatum, and $B$. dothidea were analyzed on potato dextrose agar (PDA; Difco, USA) with 0.5\% (5 g/L) peptone (PDAP) using the dual culture plate assay method (Park et al., 2013). The pathogenic fungi were applied as mycelial plugs ( $6 \mathrm{~mm}$ in diameter) from the edge of a pre-cultured colony and were placed onto the center of each PDAP plate ( $90 \mathrm{~mm}$ in diameter). Sterile paper disks ( $8 \mathrm{~mm}$ in diameter; Advantec Co., Tokyo, Japan) with $20 \mu \mathrm{l}$ of bacterial suspension $\left(10^{8} \mathrm{CFU} / \mathrm{ml}\right)$ were equidistantly placed around the fungal inoculums at a distance of $30 \mathrm{~mm}$ at $24 \mathrm{~h}$ after pathogen inoculation. PDAP inoculated with pathogen alone was used as the control. Plates were incubated at $28{ }^{\circ} \mathrm{C}$ for $7 \mathrm{~d}$. The inhibition of mycelial growth was measured as the diameter $(\mathrm{mm})$ of the inhibition zone and categorized as follows: +++ , 15-20 mm; ++, 11-14 mm; +, 8-10 mm; -, no 
inhibition zone $(0 \mathrm{~mm})$. SDW was used as the untreated control. The isolates that produced the largest zone of inhibition were selected for further study. Out of 30 isolates screened, only isolates APEC136 and APEC170 showed strong antagonistic activity against C. gloeosporioides, C. acutatum, and B. dothidea and were selected for further experiments.

\subsection{Pathogen isolation and preparation of inoculum}

Apple fruits with anthracnose and white rot symptoms were collected from Andong, Gyeongbuk Province, Korea. Symptomatic tissues were cut into small pieces with a sterile scalpel, surface-sterilized using $1 \%(0.01 \mathrm{~g} / \mathrm{ml})$ sodium hypochlorite $(\mathrm{NaOCl})$ solution for $1 \mathrm{~min}$ and $70 \%$ ethanol for $30 \mathrm{~s}$, and then rinsed twice in SDW for $1 \mathrm{~min}$. Then the tissues were dried on sterile filter paper, transferred to PDA plates, and incubated at $25{ }^{\circ} \mathrm{C}$ for $7 \mathrm{~d}$. Fungal mycelia showing outgrowth from the tissues were transferred to PDA plates at $25^{\circ} \mathrm{C}$. Isolated fungi were identified by morphological and molecular characteristics according to previous descriptions (Ogata et al., 2000; Weir et al., 2012). Conidial suspensions were prepared by suspending mycelia scraped from 7-d-old cultures of the pathogenic fungi on PDA plates. The resulting suspensions were filtered through a double-layer cheese cloth, and their concentrations were adjusted to $10^{5}$ conidia/ml using a hemocytometer.

\subsection{Identification of the antagonistic bacteria APEC136 and APEC170}

Two bacterial isolates (APEC136 and APEC170) were selected as potential candidates for the biological control of C. gloeosporioides, C. acutatum, and $B$. dothidea. They were identified based on carbon source assimilation using a Biolog GP test kit (Biolog Inc., Hayward, CA, USA) and sequencing analysis of 16S ribosomal RNA (rRNA) genes (Weisburg et al., 1991). For 16S rRNA gene sequencing analysis, genomic DNAs of both APEC136 and APEC170 were extracted from 2-d-old bacterial colonies on tryptic soy agar (TSA) using a genomic DNA extraction kit for bacteria (iNtRON Biotechnology, Seongnam, Korea), according to the manufacturer's instructions. The 16S rRNA genes were amplified using polymerase chain reaction (PCR) with Taq DNA polymerase and the primers 27F (5'-AGA GTT TGA
TCM TGG CTC AG-3') and 1492R (5'-GGY TAC CTT GTT ACG ACT T-3'). The conditions for the PCR were as follows: denaturation at $94{ }^{\circ} \mathrm{C}$ for $5 \mathrm{~min}$; 30 cycles at $94{ }^{\circ} \mathrm{C}$ for $1 \mathrm{~min}$, annealing at $56{ }^{\circ} \mathrm{C}$ for $1 \mathrm{~min}$, and extension at $72{ }^{\circ} \mathrm{C}$ for $1 \mathrm{~min}$; and a final extension at $72{ }^{\circ} \mathrm{C}$ for $5 \mathrm{~min}$, after which the reaction mixtures were cooled to $4{ }^{\circ} \mathrm{C}$. The amplified PCR products were purified using a Wizard SV Gel and PCR cleanup system (Promega, Madison, WI, USA) and were sequenced using an automated sequencer (Genetic Analyzer 3130; Applied Biosystems, Foster City, CA, USA) and the same primers. The sequences were then compared with those of reference species in the GenBank database using the NCBI-BLAST tool. Sequence alignment and phylogenetic tree construction were performed using the MEGA 4.0 program (Tamura et al., 2007).

\subsection{Growth characteristics of APEC136 and APEC170 under different conditions}

The growths of isolates APEC136 and APEC170 in different culture media, including brain-heart infusion (BHI), potato dextrose broth (PDB), NB, tryptic soy broth (TSB), and Luria-Bertani (LB) broth, were determined for the optimal population density and culture medium with the most efficient application. Single colonies of APEC136 and APEC170 were inoculated into test tubes $(20 \mathrm{~mm}$ in diameter) containing $5 \mathrm{ml}$ of growth medium and incubated at $28^{\circ} \mathrm{C}$ for $24 \mathrm{~h}$ under shaking conditions $(250 \mathrm{r} / \mathrm{min})$. The cultures $(5 \mathrm{ml})$ were then transferred to $500-\mathrm{ml}$ Erlenmeyer flasks containing $100 \mathrm{ml}$ growth medium and incubated at $28^{\circ} \mathrm{C}$ for $48 \mathrm{~h}$ with shaking at $250 \mathrm{r} / \mathrm{min}$. Cell growth was measured as turbidity at $600 \mathrm{~nm}$ using a spectrophotometer (Ultrospec 4000 Spectrophotometer; Pharmacia Biotech Ltd., Little Chalfont, UK). For optimization of $\mathrm{pH}, \mathrm{BHI}$ broth was adjusted to different $\mathrm{pH}$ values $(3,5,7$, and 9$)$ using $1.0 \mathrm{~mol} / \mathrm{L}$ $\mathrm{HCl}$ or $1.0 \mathrm{~mol} / \mathrm{L} \mathrm{NaOH}$ before autoclaving. Then, after the bacterial suspensions $\left(10^{8} \mathrm{CFU} / \mathrm{ml}\right)$ were inoculated into the autoclaved media, the cultures were incubated at $28{ }^{\circ} \mathrm{C}$ for $48 \mathrm{~h}$ under shaking conditions (180 r/min), and absorbance was measured at $600 \mathrm{~nm}$. For optimization of temperature, the isolates were cultured in BHI broth at different incubation temperatures $\left(15,20,25,30,35,40\right.$, and $\left.45{ }^{\circ} \mathrm{C}\right)$ for $48 \mathrm{~h}$ under shaking conditions $(180 \mathrm{r} / \mathrm{min})$, and absorbance was measured at $600 \mathrm{~nm}$. Each treatment 
contained five replicates, and the experiment was carried out at least twice.

\subsection{Enzymatic activities of APEC136 and APEC170}

Various enzyme activity tests were conducted to determine the antifungal mechanisms of the isolates APEC136 and APEC170. Chitinase assays were conducted according to the method developed by Roberts and Selitrennikoff (1988). Briefly, bacterial cultures were spotted on prepared minimal agar plates containing $0.3 \%(3 \mathrm{~g} / \mathrm{L})$ colloidal chitin. After $7 \mathrm{~d}$ of incubation at $30{ }^{\circ} \mathrm{C}$, the agar media were stained with iodine. The halo zone that formed around bacterial spots due to chitinase activity was measured. Amylolytic activity was also assessed according to a previously described method (Shaw et al., 1995). Briefly, 24-h-old bacterial cultures were spotted on starch agar plates and incubated at $37{ }^{\circ} \mathrm{C}$ for $24-48 \mathrm{~h}$. The plates were flooded with iodine solution and observed for starch hydrolysis, which was indicated by the formation of a halo zone around bacterial colonies. Cellulase activity assays were carried out qualitatively, using carboxymethylcellulose (CMC) as the sole carbon and energy source, as described by Hankin and Anagnostakis (1977). Briefly, CMC agar plates were inoculated with 24-h-old bacterial cultures and incubated at $28{ }^{\circ} \mathrm{C}$ for $48 \mathrm{~h}$. The development of halo zones around the colonies as a result of cellulose hydrolysis was visualized by staining with $1 \%$ Congo red dye for $15 \mathrm{~min}$, followed by destaining with $1 \mathrm{~mol} / \mathrm{L} \mathrm{NaCl}$ for $20 \mathrm{~min}$. The clear halo zones around the bacterial colonies indicated CMC-hydrolyzing capacity. Proteolytic assays were performed according to the method described by Fleming et al. (1975). Briefly, 72-h-old bacterial cultures were spotted on skim milk agar (100 ml nutrient agar supplemented with sterilized skim milk) and incubated at $28^{\circ} \mathrm{C}$ for $24-48 \mathrm{~h}$. The development of halo zones ( $\mathrm{mm}$ in diameter) around the bacterial colonies was considered to be a positive indicator of proteolysis. Each treatment contained five replicates, and the experiment was carried out at least twice.

\subsection{In vivo reduction of anthracnose and white rot diseases by APEC136 and APEC170 on harvested apples}

To investigate the potential of APEC136 and APEC170 isolates for biological control against an- thracnose and white rot diseases under in vivo conditions, freshly harvested apples were treated with suspensions of the antagonistic isolates before exposure to fungal pathogens. Apple fruits were selected to be free of wounds and homogeneous in physiological maturity and size as much as possible. Selected apple fruits were surface-sterilized using $70 \%$ ethanol for $1 \mathrm{~min}$ and $0.02 \mathrm{~g} / \mathrm{ml} \mathrm{NaOCl}$ for $5 \mathrm{~min}$, washed with sterile water, and then air-dried in a laminar airflow chamber (Kim et al., 2016). A 10- $\mu 1$ $\operatorname{drop}\left(10^{8} \mathrm{CFU} / \mathrm{ml}\right)$ of the antagonistic suspension was placed onto apple fruits that had been wounded by piercing them 1-2 $\mathrm{mm}$ deep with a sterile pin, and was allowed to dry for $10 \mathrm{~min}$. The wounds of the apple fruits were then inoculated with $10 \mu 1$ of conidial suspensions of the pathogenic fungi. Disease symptoms were observed $10 \mathrm{~d}$ after incubation at $25{ }^{\circ} \mathrm{C}$ and compared with untreated controls. Each treatment consisted of 18 replicates (fruits), and the experiment was carried out at least twice.

\subsection{Statistical analysis}

The data were subjected to analysis of variance using JMP software, Version 3.0 (SAS Institute, 1995), and treatment means were compared using the least significant difference test at $P<0.05$. The data from two experiments were combined for analysis.

\section{Results}

\subsection{Isolate selection and identification of biocon- trol agents}

The isolates APEC136 and APEC170 were selected as antagonistic bacteria against $C$. gloeosporioides, $C$. acutatum, and B. dothidea under in vitro conditions using a disc diffusion assay. The Biolog results of the two isolates showed that these isolates could be classified as $P$. polymyxa (92\% similarity, APEC136) and B. subtilis (88\% similarity, APEC170), respectively (data not shown). These two isolates were further characterized using 16S rRNA gene sequencing. A comparison of their ribosomal gene sequences with sequences in the GenBank database suggested that the isolates belonged to the genera Paenibacillus and Bacillus, respectively. The phylogenetic trees of the two isolates showed the highest homology to $P$. polymyxa $(100 \%)$ and B. subtilis 
$(100 \%)$, respectively, indicating that they grouped with other Paenibacillus and Bacillus spp. Comparative sequence analyses of $16 \mathrm{~S}$ rRNA genes of APEC136 (1467 bp) and APEC170 (1442 bp) revealed that these two isolates are members of the genera Paenibacillus and Bacillus, respectively (Fig. 1).

\subsection{In vitro antagonistic activities of APEC136 and APEC170}

The selected isolates exhibiting the largest zone of fungal growth inhibition during in vitro screening were identified as $P$. polymyxa APEC136 and $B$. subtilis APEC170. These antagonistic isolates strongly inhibited the development of fungal mycelia of C. gloeosporioides, C. acutatum, and B. dothidea compared with the untreated control (Fig. 2). However, the growth inhibitory effects of both isolates were much weaker on $B$. dothidea than on the other two fungal mycelia.

\subsection{Optimal culture medium, $\mathrm{pH}$, and tempera- ture for APEC136 and APEC170}

The growths of APEC136 and APEC170 were higher when cultured in BHI broth than when cultured
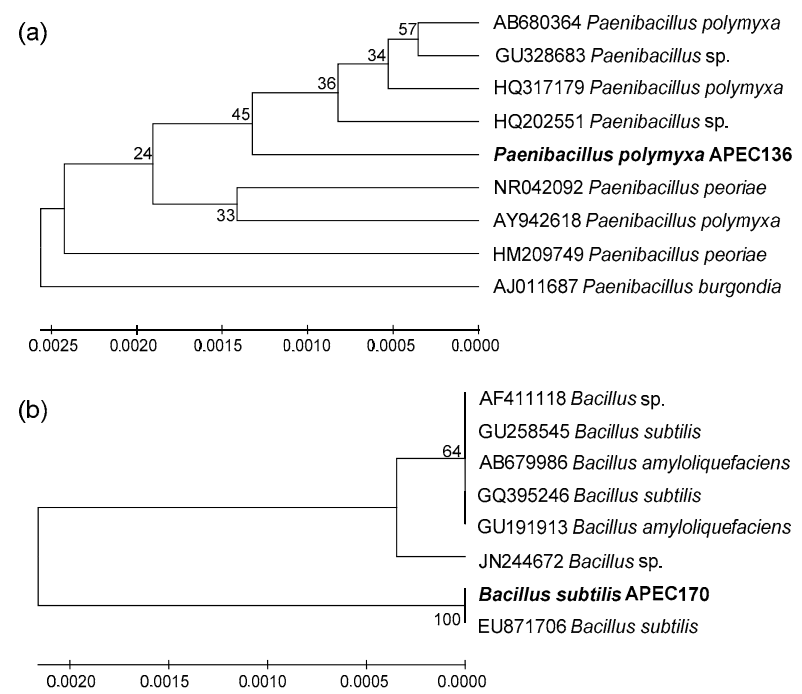

Fig. 1 Phylogenetic dendrogram inferred from the $16 \mathrm{~S}$ rRNA sequences, showing the relationships between $P$. polymyxa isolate APEC136 and related Paenibacillus species (a) and $B$. subtilis isolate APEC170 and related Bacillus species (b)

Bootstrap values (expressed as percentages of 1000 replications) greater than $50 \%$ are shown at branch points, and species names are preceded by NCBI-GenBank accession numbers. The trees were generated using maximum parsimony in MEGA 4.0. The scale bar indicates 0.02 substitutions per nucleotide position

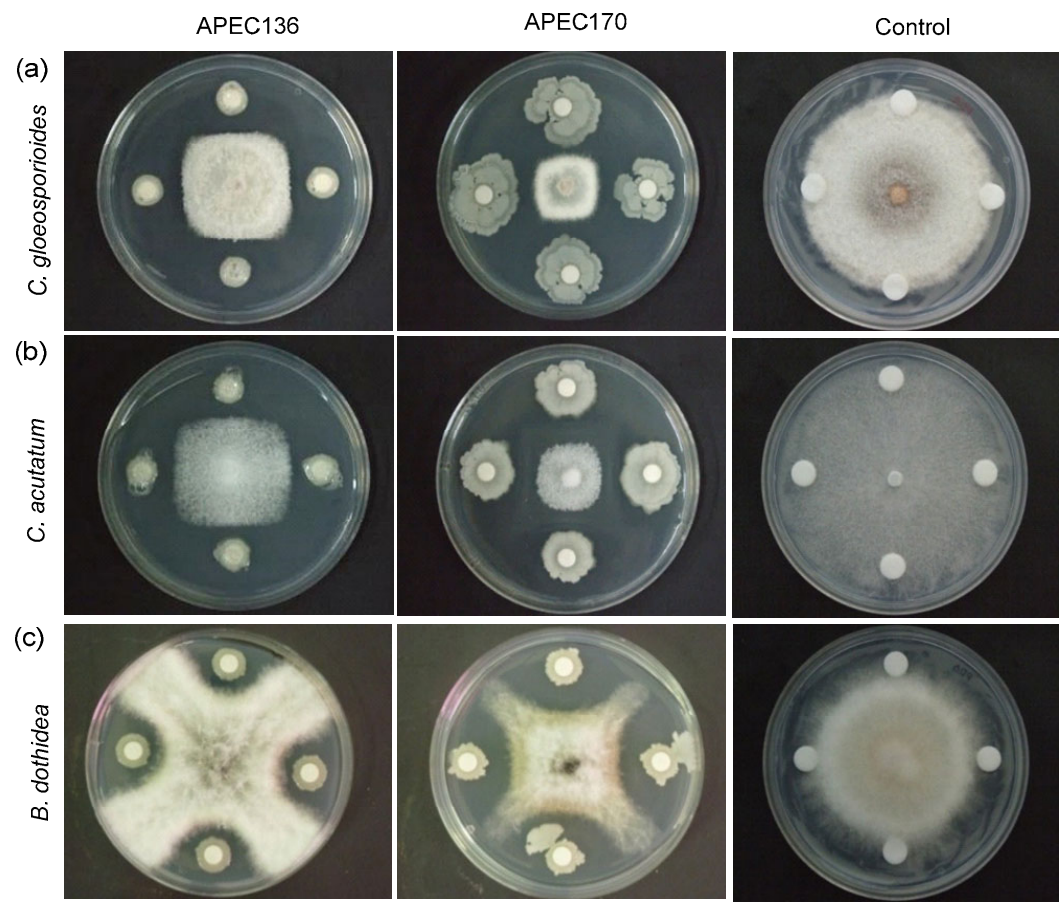

Fig. 2 Disc diffusion assays, showing the in vitro antagonistic activities of $P$. polymyxa isolate APEC136 and $B$. subtilis isolate APEC170 against C. gloeosporioides (a), C. acutatum (b), and B. dothidea (c) Photographs were taken after incubating at $25^{\circ} \mathrm{C}$ for $5 \mathrm{~d}$. Distilled water was used as the untreated control treatment $(n=5)$ 
in other media after incubation at $28{ }^{\circ} \mathrm{C}$ for $48 \mathrm{~h}$ (Fig. 3). The second most optimum growth medium was TSB, and the lowest number of bacterial cells was observed in NB medium. In addition, greater bacterial cell growth was observed at $\mathrm{pH} 7$ (Fig. 4a) compared to other treatments. The optimum temperature for bacterial cell growth was between 25 and $35{ }^{\circ} \mathrm{C}$ for APEC136, while between 25 and $30{ }^{\circ} \mathrm{C}$ for APEC170 (Fig. 4b). Temperatures above $35^{\circ} \mathrm{C}$ greatly inhibited the cell growth of both isolates, as measured by turbidity after incubation. The highest cell numbers found were $10^{8}-10^{9} \mathrm{CFU} / \mathrm{ml}$ with $\mathrm{OD}_{600}$ of 1.62 and 1.53 for APEC136 and APEC170, respectively.

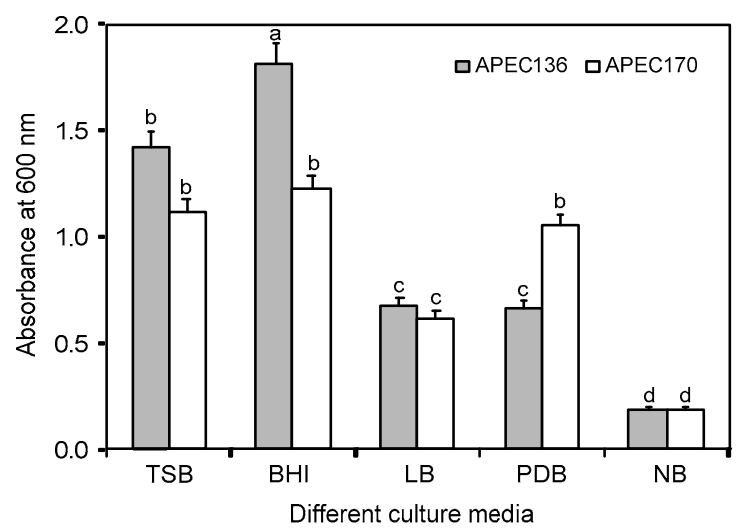

Fig. 3 Growths of P. polymyxa APEC136 and B. subtilis APEC170 on different media

$\mathrm{OD}_{600}$ was measured after incubation at $28^{\circ} \mathrm{C}$ for $48 \mathrm{~h}$. The experiment was carried out at least twice, with each consisting five replicates. Bars with the same letters do not differ significantly from each other, according to the least significant difference test at $P<0.05$. TSB: tryptic soy broth; BHI: brain-heart infusion; LB: Luria-Bertani broth; PDB: potato dextrose broth; NB: nutrient broth. Data are expressed as mean \pm standard error (SE)

\subsection{Enzyme production by APEC136 and APEC170}

APEC136 produced higher levels of amylase and protease but lower levels of chitinase and cellulose, as indicated by the zone of hydrolysis around the bacterial colonies. In contrast, APEC170 produced higher levels of chitinase and amylase than of protease and cellulose (Fig. 5). These results suggested that both isolates have the potential for producing enzymes in vitro that could contribute to antagonistic activity.
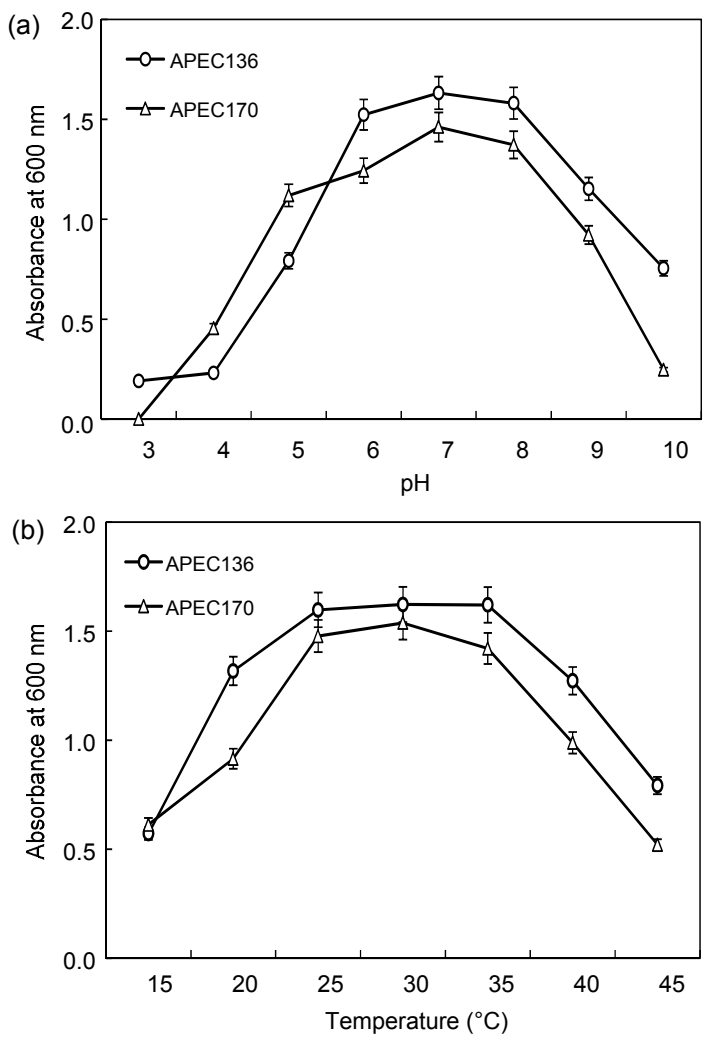

Fig. 4 Growths of $P$. polymyxa isolate APEC136 and $B$. subtilis isolate APEC170 in brain-heart infusion broth with different $\mathrm{pH}$ values (a) and temperatures (b)

Each treatment consisted of five replicates, and the experi ment was carried out at least twice. Data are expressed as mean \pm SE

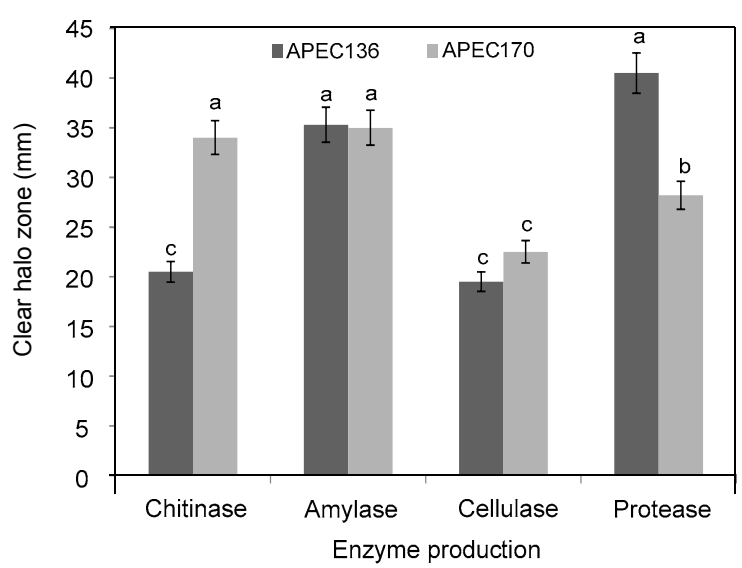

Fig. 5 Production of chitinase, amylase, cellulase, and protease enzymes by $P$. polymyxa APEC136 and $B$. subtilis APEC170, inferred from the size of halo zones under in vitro conditions

Each treatment consisted of five replicates, and the experiment was carried out at least twice. Bars with the same letters do not differ significantly from each other, according to the least significant difference test at $P<0.05$. Data are expressed as mean $\pm \mathrm{SE}$ 


\subsection{In vivo reduction of anthracnose and white rot diseases by APEC136 and APEC170 on harvested apples}

APEC136- and APEC170-treated apples showed reduced anthracnose and white rot diseases compared with untreated controls. The symptoms started to appear at $7 \mathrm{~d}$ post-inoculation for untreated controls. However, APEC136 treatment showed a greater reduction in C. gloeosporioides and C. acutatum than APEC170 treatment, whereas the white rot disease caused by $B$. dothidea was greatly reduced by both isolates compared with the untreated control. The disease lesions caused by $C$. gloeosporioides were $5.5 \mathrm{~mm}$ in diameter on APEC136-treated apples and $6.9 \mathrm{~mm}$ in diameter on APEC170-treated apples (Fig. 6a). Lesions caused by $C$. acutatum were 5.2 and $5.9 \mathrm{~mm}$ in diameter, respectively (Fig. 6b), and there were no disease lesions from $B$. dothidea on either APEC136- or APEC170-treated apples (Fig. 6c). The disease symptoms of untreated apples appeared to be three times higher than those of APEC136- and APEC170-treated apples. Fig. 7 clearly illustrates the reduction of anthracnose and white rot diseases on harvested apples after treatment with APEC136 or APEC170 suspensions, compared with untreated controls.

\section{Discussion}

The use of biocontrol agents has emerged as an alternative to synthetic fungicides for controlling postharvest diseases of fruits, to ensure public safety with regard to food contamination. This process involves screening for potential biocontrol agents based on antagonistic activity. Conidia are the major source of contamination both in the field and under postharvest conditions for many plant diseases, including anthracnose and white rot. Our in vitro results confirmed strong inhibitory activities of the isolates APEC136 and APEC170 on the mycelial growth of the apple fungal pathogens $C$. gloeosporioides and $C$. acutatum and a weaker inhibitory effect on $B$. dothidea (Fig. 2). These results are similar to those of Lee et al. (2012), who reported inhibition of spore germination of several pathogens under in vitro conditions. In the present study, the isolates APEC136 and APEC170 also reduced the size of lesions in apples resulting from anthracnose and white rot diseases. (a)

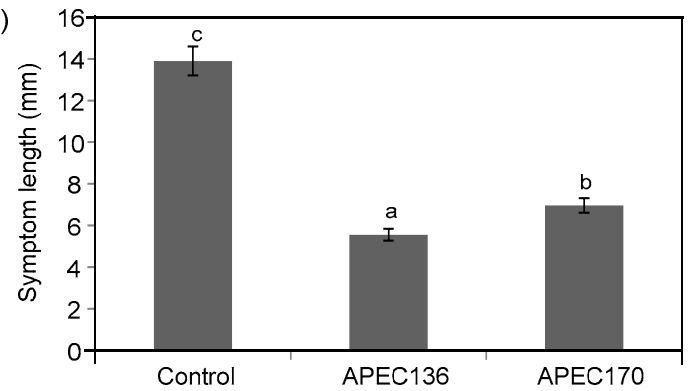

(b)

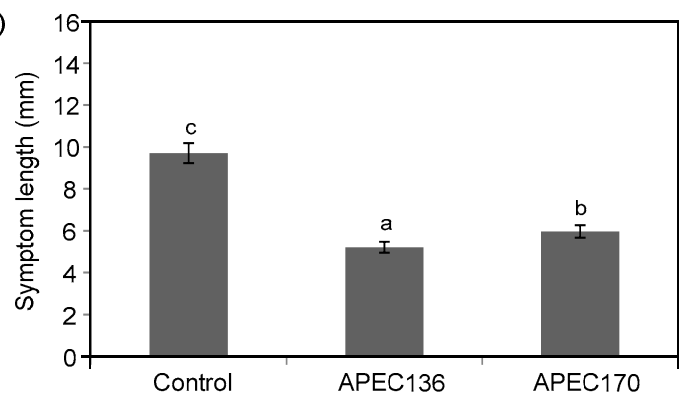

(c)

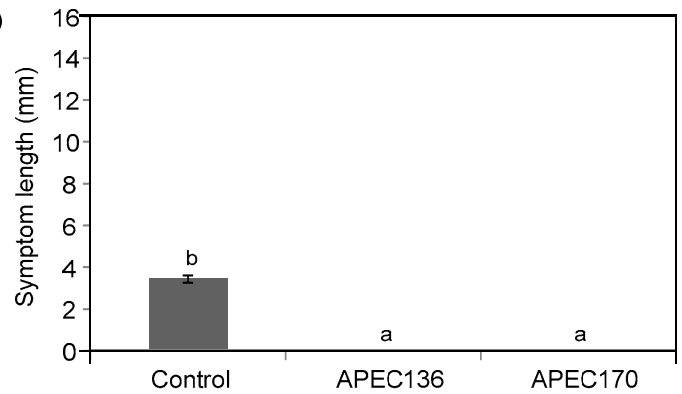

Fig. 6 In vivo assay of spore development reductions of C. gloeosporioides (a), C. acutatum (b), and B. dothidea (c) on harvested apples after treatment with $P$. polymyxa APEC136 and $B$. subtilis APEC170 suspensions $\left(1 \times 10^{8} \mathrm{CFU} / \mathrm{ml}\right)$, compared with untreated controls after $10 \mathrm{~d}$ of incubation at $25^{\circ} \mathrm{C}$

Each treatment consisted of 18 replicates (fruits), and the experiment was carried out at least twice. Bars with the same letters do not differ significantly from each other, according to the least significant difference test at $P<0.05$. Data are expressed as mean $\pm \mathrm{SE}$

Touré et al. (2004) reported that the bacterium $B$. subtilis is an effective biocontrol agent that produces fengycins, which efficiently protect apple fruits against $B$. cinerea under controlled conditions. $B$. subtilis has also been reported as an antagonist to other postharvest diseases in fruits, including apples and pears (Qi et al., 2005; Yánez-Mendizábal et al., 2011). The biocontrol efficiency of B. subtilis is mainly attributable to the production of several antifungal compounds, such as chitinases, glucanases, 


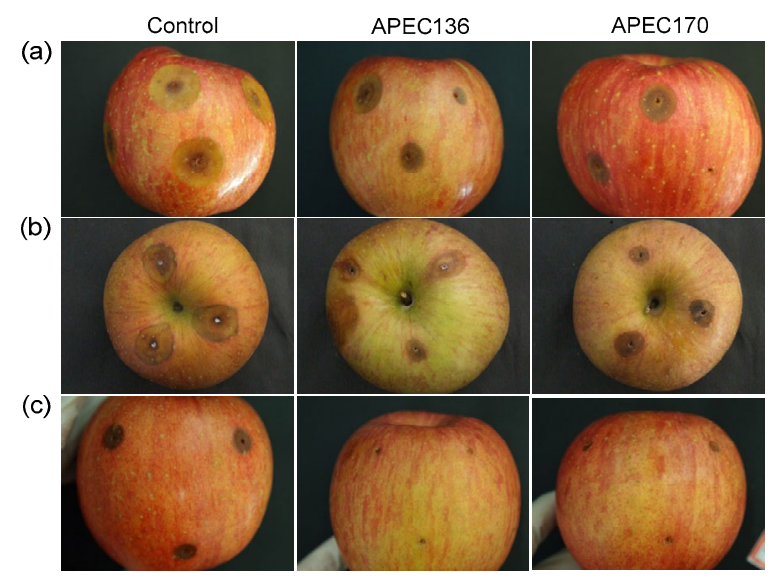

Fig. 7 In vivo assay of spore development reductions of C. gloeosporioides (a), C. acutatum (b), and B. dothidea (c) on harvested apples after treatment with $P$. polymyxa isolate APEC136 and B. subtilis isolate APEC170 suspensions $\left(1 \times 10^{8} \mathrm{CFU} / \mathrm{ml}\right)$ compared with untreated controls

The photographs were taken $10 \mathrm{~d}$ after incubation at $25^{\circ} \mathrm{C}$

surfactin, iturin, and gramicidin (Cho et al., 2003; Ongena et al., 2005; Yánez-Mendizábal et al., 2011). In this study, $\mathrm{pH}$ and temperature conditions also affected the growths of APEC136 and APEC170 isolates. Our results are supported by those of Vijayalakshmi et al. (2012) who found that the production of extracellular enzymes and antibiotics by other Bacillus spp. was dependent on $\mathrm{pH}$ and temperature. In addition, a recent study by Kim et al. (2016) demonstrated the potential of $P$. polymyxa for the biocontrol of anthracnose disease in apple. Similarly, a reduction of white rot disease caused by Coniella diplodiella in table grapes was observed by Han et al. (2015).

The multiple modes of action of Paenibacillus and Bacillus spp. are assumed to contribute to their biocontrol activity and include competition for nutrients, induced resistance, and the production of antibiotics and cell wall-degrading enzymes such as chitinases and $\beta-1,3$-glucanase (Berg, 2009; Droby et al., 2009). Many studies have reported the importance of a range of antifungal compounds produced by Bacillus spp. in biocontrol activity (Kong et al., 2012; Zhang et al., 2013). Recently, Kim et al. (2015) reported that treating harvested apples with $B$. subtilis suspensions yielded a greater reduction in disease severity caused by $C$. acutatum than that with the culture filtrate. The isolates APEC136 and
APEC170 greatly reduced the growths of $C$. gloeosporioides and $C$. acutatum pathogens in vitro, probably owing to their production of antifungal compounds. Janisiewicz and Korsten (2002) reported that lytic enzymes produced by Bacillus spp. may play a role in their biocontrol activity. In vivo assays demonstrated a greater reduction of $B$. dothidea than of the other two pathogens that cause anthracnose disease. In addition, Yánez-Mendizábal et al. (2012) demonstrated the ability of $B$. subtilis CPA- 8 to control Monilinia spp., which cause brown rot disease in peaches by producing fengycin-like lipopeptides. Similarly, B. subtilis CPA-8 also showed antifungal activity against various postharvest pathogens such as Botrytis cinerea, Monilinia laxa, Moilinia fructicola, Penicillium digitatum, Penicillium expansum, and Penicillium italicum (Yánez-Mendizábal et al., 2012).

In conclusion, our findings demonstrated that APEC136 and APEC170 isolates exhibited stronger in vitro antifungal activity against $C$. gloeosporioides and $C$. acutatum than against $B$. dothidea. In vivo, only APEC136 reduces the white rot disease caused by $B$. dothidea. Moreover, postharvest treatment with suspensions of APEC136 and APEC170 resulted in significant reductions in disease development during storage at room temperature. Thus, our results indicated that both isolates are promising agents for the biocontrol of apple diseases after harvest and under field conditions. However, further studies are required to elucidate the mechanisms involved in these processes.

\section{Compliance with ethics guidelines}

Young Soo KIM, Kotnala BALARAJU, and Yongho JEON declare that they have no conflict of interest.

This article does not contain any studies with human or animal subjects performed by any of the authors.

\section{References}

Berg, G., 2009. Plant-microbe interactions promoting plant growth and health: perspectives for controlled use of microorganisms in agriculture. Appl. Microbiol. Biotechnol., 84(1):11-18. http://dx.doi.org/10.1007/s00253-009-2092-7

Chen, X., Zhang, Y., Fu, X., et al., 2016. Isolation and characterization of Bacillus amyloliquefaciens PG12 for the biological control of apple ring rot. Postharvest Biol. Technol., 115:113-121. http://dx.doi.org/10.1016/j.postharvbio.2015.12.021 
Cho, S.J., Lee, S.K., Cha, B.J., et al., 2003. Detection and characterization of the Gloeosporium gloeosporioides growth inhibitory compound iturin A from Bacillus subtilis strain KS03. FEMS Microbiol. Lett., 223(1):47-51. http://dx.doi.org/10.1016/S0378-1097(03)00329-X

Choi, I.Y., 2011. First report of bark dieback on blueberry caused by Botryosphaeria dothidea in Korea. Plant Dis., 95(2):227. http://dx.doi.org/10.1094/PDIS-05-10-0371

Dhingra, O.D., Sinclair, J.B., 1985. Basic Plant Pathology Methods. CRC Press Inc., Boca Raton, FL, USA, p.355.

Dijksterhuis, J., Sanders, M., Gorris, L.G.M., et al., 1999. Antibiosis plays a role in the context of direct interaction during antagonism of Paenibacillus polymyxa towards Fusarium oxysporum. J. Appl. Microbiol., 86(1):13-21. http://dx.doi.org/10.1046/j.1365-2672.1999.t01-1-00600.x

Droby, S., 2006. Biological control of postharvest diseases of fruits and vegetables: difficulties and challenges. Phytopathol. Pol., 39:105-117.

Droby, S., Wisniewski, M., Macarisin, D., et al., 2009. Twenty years of postharvest biocontrol research: is it time for a new paradigm? Postharvest Biol. Technol., 52(2):137-145. http://dx.doi.org/10.1016/j.postharvbio.2008.11.009

Fleming, H.P., Etchells, J.L., Costilow, R.N., 1975. Microbial inhibition by an isolate of Pediococcus from cucumber brines. Appl. Microbiol., 30(6):1040-1042.

Haas, D., Défago, G., 2005. Biological control of soil-borne pathogens by fluorescent pseudomonads. Nat. Rev. Microbiol., 3:307-319.

https://dx.doi.org/10.1038/nrmicro1129

Han, J., Chen, D., Huang, J., et al., 2015. Antifungal activity and biocontrol potential of Paenibacillus polymyxa HT16 against white rot pathogen (Coniella diplodiella Speq.) in table grapes. Biocont. Sci. Technol., 25(10):1120-1132. https://dx.doi.org/10.1080/09583157.2015.1036003

Hankin, L., Anagnostakis, S.L., 1977. Solid media containing carboxymethylcellulose to detect $\mathrm{C}_{\mathrm{x}}$ cellulase activity of micro-organisms. Microbiology, 98(1):109-115. http://dx.doi.org/10.1099/00221287-98-1-109

Heulin, T., Berge, O., Mavingui, P., et al., 1994. Bacillus polymyxa and Rahnella aquatilis, the dominant $\mathrm{N}_{2}$-fixing bacteria associated with wheat rhizosphere in French soils. Eur. J. Soil Biol., 30(1):35-42.

Janisiewicz, W.J., Korsten, L., 2002. Biological control of postharvest diseases of fruits. Annu. Rev. Phytopathol., 40:411-441. http://dx.doi.org/10.1146/annurev.phyto.40.120401.130158

Kelman, A., 1989. Introduction: the importance of research on the control of postharvest diseases of perishable food crops. Phytopathol., 79(12):1374.

Kim, H.M., Lee, K.J., Chae, J.C., 2015. Postharvest biological control of Colletotrichum acutatum on apple by Bacillus subtilis HM1 and the structural identification of antagonists. J. Microbiol. Biotechnol., 25(11):1954-1959. http://dx.doi.org/10.4014/jmb.1507.07100

Kim, K.W., Kim, K.R., Park, E.W., 2005. An infection model of apple white rot based on conidial germination and appressorium formation of Botryosphaeria dothidea. Plant Pathol. J., 21(4):322-327.
http://dx.doi.org/10.5423/PPJ.2005.21.4.322

Kim, Y.S., Balaraju, K., Jeon, Y., 2016. Biological control of apple anthracnose by Paenibacillus polymyxa APEC128, an antagonistic rhizobacterium. Plant Pathol. J., 32(3): 251-259. http://dx.doi.org/10.5423\%2FPPJ.OA.01.2016.0015

Kong, H.G., Kim, J.C., Choi, G.J., et al., 2012. Production of surfactin and iturin by Bacillus licheniformis N1 responsible for plant disease control activity. Plant Pathol. J., 26(2):170-177. http://dx.doi.org/10.5423/PPJ.2010.26.2.170

Lee, D.H., Kim, D.H., Jeon, Y.A., et al., 2007. Molecular and cultural characterization of Colletotrichum spp. causing bitter rot of apples in Korea. Plant Pathol. J., 23(2):37-44. http://dx.doi.org/10.5423/PPJ.2007.23.2.037

Lee, G.W., Ko, J.A., Oh, B.T., et al., 2012. Biological control of postharvest diseases of apples, peaches and nectarines by Bacillus subtilis S16 isolated from halophytes rhizosphere. Biocont. Sci. Technol., 22(3):351-361. http://dx.doi.org/10.1080/09583157.2012.658553

Li, J., Liu, W., Luo, L., et al., 2015. Expression of Paenibacillus polymyxa $\beta-1,3-1,4-$ glucanase in Streptomyces lydicus A01 improves its biocontrol effect against Botrytis cinerea. Biol. Cont., 90:141-147. http://dx.doi.org/10.1016/j.biocontrol.2015.06.008

Liu, J., Sui, Y., Wisniewski, M., et al., 2013. Review: utilization of antagonistic yeasts to manage postharvest fungal diseases of fruit. Int. J. Food Microbiol., 167(2):153-160. http://dx.doi.org/10.1016/j.ijfoodmicro.2013.09.004

Mari, M., Neri, F., Bertolini, P., 2009. Management of important diseases in Mediterranean high value crops. Stewart Postharvest Rev., 5(2):1-10. https://doi.org/10.2212/spr.2009.2.2

Mari, M., Guidarelli, M., Martini, C., et al., 2012. First report of Colletotrichum acutatum causing bitter rot on apple in Italy. Plant Dis., 96(1):144. http://dx.doi.org/10.1094/PDIS-06-11-0483

Ogata, T., Sano, T., Harada, Y., 2000. Botryosphaeria spp. isolated from apple and several deciduous fruit trees are divided into three groups based on the production of warts on twigs, size of conidia, and nucleotide sequences of nuclear ribosomal DNA ITS regions. Mycoscience, 41(4):331-337. https://doi.org/10.1007/BF02463946

Ongena, M., Jacques, P., 2008. Bacillus lipopeptides: versatile weapons for plant disease biocontrol. Trends Microbiol., 16(3):115-125 http://dx.doi.org/10.1016/j.tim.2007.12.009

Ongena, M., Jacques, P., Touré, Y., et al., 2005. Involvement of fengycin-type lipopeptides in the multifaceted biocontrol potential of Bacillus subtilis. Appl. Microbiol. Biotechnol., 69(1):29-38. http://dx.doi.org/10.1007/s00253-005-1940-3

Park, J.W., Balaraju, K., Kim, J.W., et al., 2013. Systemic resistance and growth promotion of chili pepper induced by an antibiotic producing Bacillus vallismortis strain BS07. Biol. Cont., 65(2):246-257. http://dx.doi.org/10.1016/j.biocontrol.2013.02.002

Piggot, P.J., Hilbert, D.W., 2004. Sporulation of Bacillus 
subtilis. Curr. Opin. Microbiol., 7(6):579-586.

Qi, D.M., Hui, M., Liang, Q.M., et al., 2005. Postharvest biological control of blue mold and black spot on applepear (Pyrus bretschneideri Rehd.) fruit by Bacillus subtilis H110. Chin. J. Appl. Environ. Biol., 11(2):171-174.

Roberts, W.K., Selitrennikoff, C.P., 1988. Plant and bacterial chitinases differ in antifungal activity. Microbiology, 134:169-176. http://dx.doi.org/10.1099/00221287-134-1-169

Rosado, A.S, Seldin, L., 1993. Production of a potentially novel antimicrobial substance by Bacillus polymyxa. World J. Microbiol. Biotechnol., 9(5):521-528.

SAS Institute, 1995. JMP Statistics and Graphics Guide. SAS Institute Inc., Cary, North Carolina, Version 3.1, p.65-95.

Shaw, J.F., Lin, F.P., Chen, S.C., et al., 1995. Purification and properties of an extracellular $\alpha$ amylase from Thermos sp. Bot. Bull. Acad. Sin., 36(3):195-200.

Singh, H.P., Singh, T.A., 1993. The interaction of rockphosphate, Bradyrhizobium, vesicular-arbuscular mycorrhizae and phosphate-solubilizing microbes on soybean grown in a sub-Himalayan mollisol. Mycorrhiza, 4(1):37-43. http://dx.doi.org/10.1007/BF00203249

Talibi, I., Boubaker, H., Boudyach, E.H., et al., 2014. Alternative methods for the control of postharvest citrus diseases. J. Appl. Microbiol., 117(1):1-17. http://dx.doi.org/10.1111/jam.12495

Tamura, K., Dudley, J., Nei, M., et al., 2007. MEGA4: molecular evolutionary genetics analysis (MEGA) software version 4.0. Mol. Biol. Evol., 24(8):1596-1599. https://dx.doi.org/10.1093/molbev/msm092

Tang, W., Ding, Z., Zhou, Z.Q., et al., 2012. Phylogenetic and pathogenic analyses show that the causal agent of apple ring rot in China is Botryosphaeria dothidea. Plant Dis., 96(4):486-496.

http://dx.doi.org/10.1094/PDIS-08-11-0635

Teixidó, N., Torres, R., Viñas, I., et al., 2011. Biological control of postharvest diseases in fruit and vegetables. In: Lacroix, C. (Ed.), Protective Cultures, Antimicrobial Metabolites and Bacteriophages for Food and Beverage Biopreservation. Woodhead Publishing Limited, Cambridge, UK, p.364-402. http://dx.doi.org/10.1533/9780857090522.3.364

Touré, Y., Ongena, M., Jacques, P., et al., 2004. Role of lipopeptides produced by Bacillus subtilis GA1 in the reduction of grey mould disease caused by Botrytis cinerea on apple. J. Appl. Microbiol., 96(5):1151-1160. http://dx.doi.org/10.1111/j.1365-2672.2004.02252.x

Vijayalakshmi, K.S., Abha, S., Chander, P., 2012. Isolation and characterization of Bacillus subtilis $\mathrm{KC} 3$ for amylolytic activity. Inter. J. Biosci. Biochem. Bioinform., 2(5): 336-341. http://dx.doi.org/10.7763/IJBBB.2012.V2.128

Weir, B.S., Johnston, P.R., Damm, U., 2012. The Colletotrichum gloeosporioides species complex. Stud. Mycol., 73:115-180.

Weisburg, W.G., Barns, S.M., Pelletier, D.A., et al., 1991. 16S ribosomal DNA amplification for phylogenetic study. $J$. Bacteriol., 173(2):697-703.

Wharton, P.S., Diéguez-Uribeondo, J., 2004. The biology of
"Colletotrichum acutatum". Anal. Jardín Botánico Madrid, 61(1):3-22.

Yánez-Mendizábal, V., Usall, J., Viñas, I., et al., 2011. Potential of a new strain of Bacillus subtilis CPA-8 to control the major postharvest diseases of fruit. Biocont. Sci. Technol., 21(4):409-426. http://dx.doi.org/10.1080/09583157.2010.541554

Yánez-Mendizábal, V., Zeriouh, H., Viñas, I., et al., 2012. Biological control of peach brown rot (Monilinia spp.) by Bacillus subtilis CPA-8 is based on production of fengycin-like lipopeptides. Eur. J. Plant Pathol., 132(4): 609-619.

http://dx.doi.org/10.1007/s10658-011-9905-0

Zhang, Z., Yang, D., Yang, B., et al., 2013. $\beta$-Aminobutyric acid induces resistance of mango fruit to postharvest anthracnose caused by Colletotrichum gloeosporioides and enhances activity of fruit defense mechanisms. Sci. Hort., 160:78-84.

Zhu, S.J., 2006. Non-chemical approaches to decay control in postharvest fruit. In: Noureddine, B., Norio, S. (Eds.), Advances in Postharvest Technologies for Horticultural Crops. Research Signpost, Trivandrum, India, p.297-313.

\section{中文概要}

题 目: 多粘类芽孢杆菌 APEC136 和枯草芽孢杆菌 APEC170 对苹果采后病害生物防治的影响

目 的: 研究 APEC136 和 APEC170 对苹果采后炭疽病和 白腐病的生物防治作用。

方 法: 选择 APEC136 和 APEC170 两菌株为对象, 通过 16S rRNA 序列分析进行菌种鉴定; 研究不同的 培养基、温度和 $\mathrm{pH}$ 值等条件对 APEC136 和 APEC170 生长影响; 测定其对几丁质酶, 淀粉酶, 纤维素酶和蛋白酶的产量和活性的影响; 分析其 对胶孢炭疽菌 (Colletotrichum gloeosporioides)、 尖狍炭疽 (Colletotrichum acutatum) 和葡萄座腔 菌（Botryosphaeria dothidea）的菌丝生长抑制作 用, 观察苹果采后炭疽病和白腐病症状的变化。

结 论: $16 \mathrm{~S}$ rRNA 序列分析结果发现两个拮抗菌株分别 为多粘类芽孢杆菌和枯草芽孢杆菌。在脑心浸液 肉汤（BHI）培养基中, 这两个菌株生长最快。 体外生物测定表明, 在篮选的 30 株菌株中, APEC136 和 APEC170 对胶狍炭疽菌、尖孢炭疽 和葡萄座腔菌的菌丝生长的抑制作用最显著。 APEC136 和 APEC170 均减轻了苹果采后由病原 真菌引起的炭疽病和白腐病症状。另外, APEC136 增加了淀粉酶和蛋白酶产量, APEC170 增加了几丁质酶、淀粉酶和蛋白酶产量, 这些可 能是其抑制菌丝生长的原因。综上所述, 菌株 APEC136 和 APEC170 是有效的苹果采后炭疽病 和白腐病的生物防治剂, 可用于野外条件下的疾 病控制。

关键词: 炭疽病; 拮抗活性; 生物防治; 白腐病; 苹果 